\title{
PENGARUH BEBERAPA RASIO KEUANGAN TERHADAP KEPUTUSAN HEDGING PADA SEKTOR PERTAMBANGAN DI BURSA EFEK INDONESIA
}

\author{
Putu Mia Anggyantari ${ }^{1}$ \\ Ida Bagus Anom Purbawangsa ${ }^{2}$ \\ ${ }^{1,2}$ Fakultas Ekonomi dan Bisnis Universitas Udayana (Unud), Bali, Indonesia \\ email: miaanggyantari5@gmail.com
}

\begin{abstract}
ABSTRAK
Perusahaan yang melakukan perdagangan internasional akan terkena dampak perubahan nilai mata uang asing yang tidak terduga, sehingga perusahaan perlu melakukan hedging instrumen derivatif. Penelitian ini bertujuan untuk menganalisis pengaruh beberapa rasio keuangan, seperti likuiditas, leverage dan profitabilitas terhadap keputusan hedging instrumen derivatif. Penelitian ini menggunakan data sekunder yang berasal dari laporan tahunan perusahaan. Populasi adalah perusahaan pertambangan yang terdaftar di BEI periode 2016-2018. Pengambilan sampel menggunakan purposive sampling dengan 33 perusahaan dianalisis dengan analisis regresi logistik. Hasil penelitian ini menemukan bahwa likuiditas berpengaruh negatif signifikan terhadap keputusan hedging instrumen derivatif, leverage berpengaruh positif signifikan terhadap keputusan hedging instrumen derivatif, profitabilitas berpengaruh negatif signifikan terhadap keputusan hedging instrumen derivatif. Ketepatan data prediksi probabilitas hedging instrumen derivatif pada perusahaan sebesar $28 \%$ dan sisanya sebesar $72 \%$ dijelaskan oleh variabel lain diluar model.
\end{abstract}

Kata kunci :Likuiditas, Leverage, Profitabilitas, dan Hedging

\begin{abstract}
Companies that conduct international trade will be affected by unexpected changes in the value of foreign currencies, so companies need to hedge derivative instruments. This study aims to analyze the effect of several financial ratios, such as liquidity, leverage and profitability on hedging decisions on derivative instruments. This study uses secondary data from the company's annual report. The population is a mining company listed on the Indonesia Stock Exchange for 2016-2018. Purposive sampling is used with 33 companies analyzed by logistic regression analysis. Liquidity has significant negative effect on hedging decisions of derivative instruments, leverage has significant positive effect on hedging decisions of derivative instruments, profitability has significant negative effect on hedging decisions of derivative instruments. The accuracy of the prediction data for the probability of hedging derivative instruments in companies is $28 \%$ and the remaining $72 \%$ is explained by other variables outside the model.
\end{abstract}

Keywords:Liquidity, Leverage, Profitability, and Hedging 


\section{PENDAHULUAN}

Perkembangan perdagangan pada era globalisasi saat ini sangat memegang peranan penting dalam perekonomian suatu negara. Perdagangan kini tidak hanya berkembang di dalam negeri saja, malainkan perdagangan ke luar negeri atau yang biasa disebut dengan perdagangan internasional. Perdagangan internasional merupakan salah satu cara untuk melakukan ekspansi pasar, baik dengan cara mengekspor maupun mengimpor. Transaksi yang terjadi dalam perdagangan internasional berbeda dengan transaksi perdagangan dalam negeri. Pada transaksi perdagangan internasional akan melibatkan beberapa negara dengan berbagai mata uang yang berbeda-beda.

Transaksi yang melibatkan mata uang yang berbeda dapat menimbulkan risiko keuangan bagi perusahaan multinasional yang diakibatkan oleh perubahan nilai tukar mata uang asing. Transaksi tersebut dapat memberi keuntungan maupun kerugian karena perusahaan yang melakukan perdagangan internasional tidak hanya akan melakukan transaksi secara tunai, dimana akan adanya piutang maupun hutang dalam bentuk valuta asing. Banyaknya aktivitas dalam perdagangan internasional akan menyebabkan adanya peningkatan risiko yang lebih tinggi dibandingkan aktivitas dalam perdagangan dalam negeri.

Risiko merupakan kemungkinan terjadinya kerugian dari kejadian yang tidak diinginkan. Kerugian yang tidak diinginkan tersebut muncul dari berbagai sumber, seperti kerugian karena perubahan harga. Risiko dapat terjadi pada semua perusahaan, terlebih lagi perusahaan yang melakukan perdagangan internasional. Terjadinya risiko pada perdagangan internasional dapat disebabkan oleh beberapa faktor diantaranya seperti hukum, budaya, politik, kondisi perekonomian, penggunaan mata uang asing beserta faktor lainnya yang berbeda di setiap negara. Salah satu faktor yang dapat diambil sebagai contoh yaitu penggunaan mata uang asing.

Penggunaan mata uang asing dapat menimbulkan terjadinya risiko dalam transaksi internasional, risiko tersebut yaitu risiko fluktuasi kurs valuta asing (Krisdian \& Badjra, 2017). Risiko ini akan selalu mempengaruhi aktivitas perdagangan internasional, khususnya perusahaan multinasional yang ada di Indonesia. Mengingat di Indonesia sendiri menerapkan kebijakan makro pemerintah dengan sistem kurs mengambang bebas (free floating rate), dalam sistem ini tidak adanya campur tangan pemerintah terhadap tingkat nilai tukar, sehingga nilai tukar diserahkan pada permintaan dan penawaran (Ariani \& Sudiartha, 2017). Tujuan dari penerapan sistem ini untuk mencapai posisi keseimbangan sesuai dengan keadaan pasar. Perusahaan dapat memprediksi risiko yang akan terjadi dengan mengukur terlebih dahulu eksposur yang dapat dialami perusahaan. Risiko yang akan dihadapi perusahaan akan lebih kompleks, sehingga perlu adanya manajemen risiko dalam suatu perusahaan.

Grafik dibawah ini merupakan tampilan fluktuasi nilai tukar rupiah terhadap dollar Amerika dari tahun 2016-2018 yang dapat dilihat pada Gambar 1. 


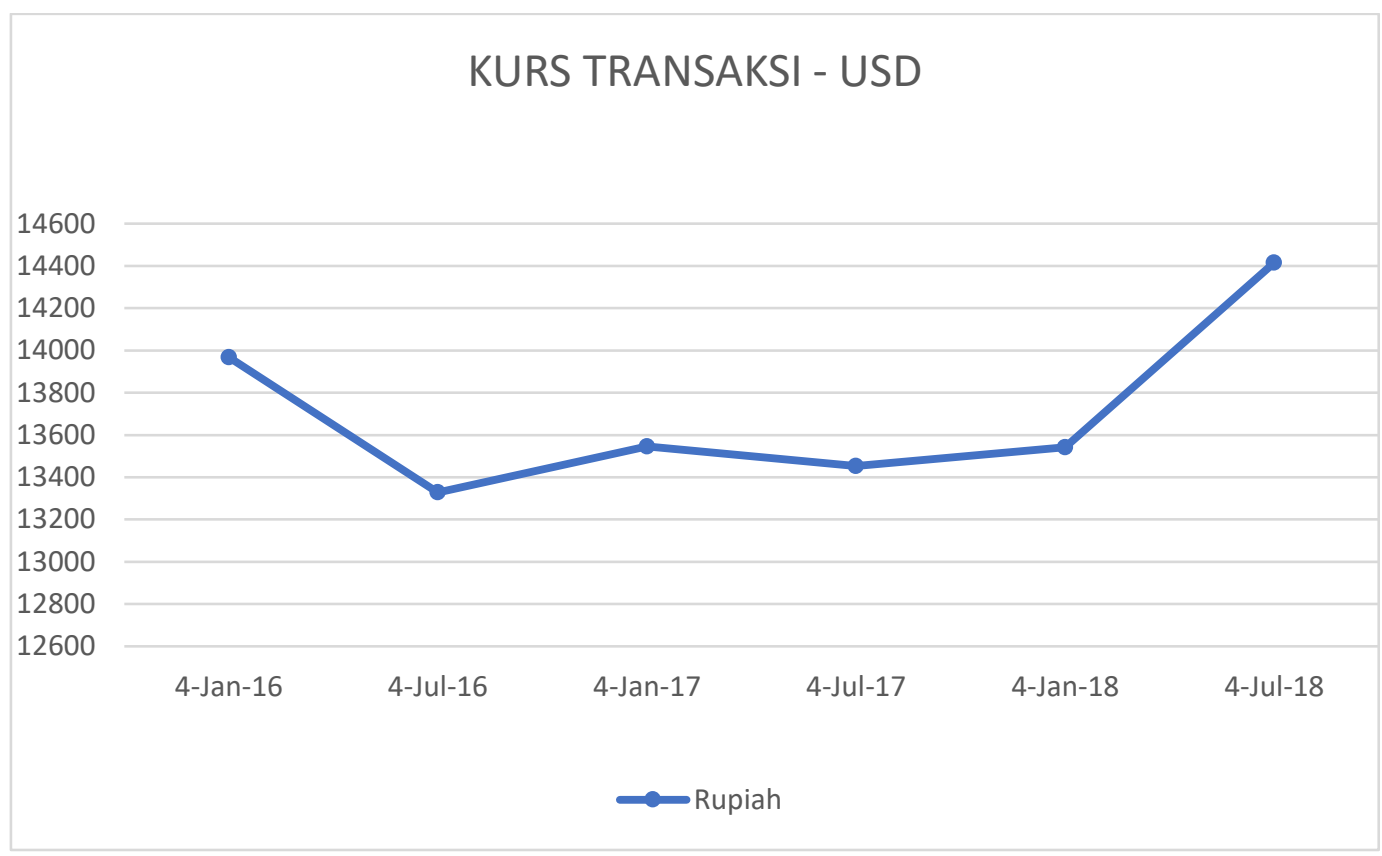

\section{Gambar 1. Nilai Tukar Rupiah terhadap Dolar AS}

Gambar 1. menunjukkan terjadinya fluktuasi kurs dollar (USD) terhadap rupiah (IDR) dari tahun 2016 hingga tahun 2018. Gambar grafik kurs transaksi USD tersebut menunjukkan bahwa kurs transaksi USD tehadap IDR selama 3 tahun terakhir dimulai dari tanggal 4 Januari 2016 hingga 4 Juli 2018. Berdasarkan gambar di atas dapat dilihat bahwa terdapat kurs terendah pada tanggal 4 Juli 2016 sebesar Rp. 13.238 dan kurs tertinggi pada tanggal 4 Juli 2018 sebesar Rp. 14.415.

Berdasarkan data yang ditunjukkan di atas mengartikan bahwa kurs USD berfluktuasi terhadap IDR. Ketika suatu perusahaan ingin melakukan kegiatan transaksi perdagangan internasional baik dalam ekspor maupun impor, akan selalu mengalami risiko fluktuasi terhadap eksposur valuta asing. Jika IDR mengalami depresiasi atau ketika mata uang USD mengalami apresiasi, maka harga impor barang akan lebih mahal dalam transaksi internasional sehingga dapat berdampak pada kenaikkan harga yang juga akan mengalami peningkatan, lain halnya jika dalam suatu perusahaan melakukan hedging dengan menggunakan instrumen derivatif yang akan membantu perusahaan meminimalisir risiko fluktuasi nilai tukar yang akan dihadapi.

Strategi hedging yang menggunakan beberapa kontrak instrumen derivatif merupakan salah satu alternatif dalam pasar modal yang cukup berperan untuk kegiatan transaksi perdagangan internasional. Instrumen derivatif merupakansuatu kontrak perjanjian antara dua pihak yang menjual ataupun membeli sejumlah aset baik berupa aktiva finansial maupun komoditas pada waktu yang telah ditentukan di masa mendatang dengan harga yang telah disepakati sebelumnya. Hedging menggunakan beberapa instrumen derivatif valuta asing sebagai satu cara untuk meminimalisir risiko fluktuasi nilai tukar, 
diantaranya adalah dengan melakukan kontrak opsi mata uang, swap mata uang, kontrak forward dan kontrak berjangka (future contract).

Keputusan hedging pada umumnya dilakukan untuk menghindari risiko financial distress yang dapat menyebabkan perusahaan mengalami kebangkrutan. Financial Distress merupakan suatu kondisi ketika perusahaan mengalami penurunan keuangan sebelum perusahaan tersebut mengalami kebangkrutan atau likuidasi. Terjadinnya keadaan tersebut dikarenakan perusahaan mengalami kekurangan modal dengan beban biaya utang dan bunga yang lebih besar dibandingkan aset yang dimiliki (High Leverage), financial distress juga dapat disebabkan oleh rendahnya tingkat profitabilitas suatu perusahaan untuk menghasilkan laba dari proses operasinya. Jika dilihat dari kondisi keuangan ada tiga faktor yang dapat menyebabkan perusahaan mengalami financial distress yaitu faktor ketidakcukupan modal atau kekurangan modal, besarnya beban utang dan bunga serta menderita kerugian (Afriyeni \& Jumyetti, 2017). Biaya-biaya transaksi yang berkaitan dengan risiko financial distress merupakan biaya yang rentan terkena fluktuasi valuta asing sebagai akibat dari adanya aktivitas transaksi perdagangan internasional yang dilakukan oleh perusahaan (Jiwandhana \& Triaryati, 2016). Dengan penggunaan Hedging dalam perusahaan dapat membantu perusahaan untuk mengunci nilai valuta asing di masa depan yang menjamin bahwa perusahaan tidak akan dirugikan oleh adanya fluktuasi mata uang (Maniar, 2016).

Faktor - faktor yang dapat mendorong perusahaan melakukan aktivitas hedging yaitu berasal dari eksternal perusahaan dan juga internal perusahaan. Terdapat dua faktor eksternal yaitu BI rate dan fluktuasi nilai tukar, sedangkan faktor-faktor internal yang mendorong perusahaan melakukan aktivitas hedging yaitu kondisi dari rasio keuangan perusahaan tersebut. Rasio keuangan dikelompokkan menjadi lima yaitu rasio likuiditas, rasio rentabilitas / profitabilitas, rasio solvabilitas / leverage, rasio aktivitas dan rasio investasi. Beberapa peneliti terdahulu sudah meneliti faktor-faktor internal berupa beberapa rasio keuangan yang mempengaruhi keputusan hedging perusahaan, diantaranya adalah Likuiditas (Mediana \& Muharam, 2016), Leverage (Yavas, 2016)dan Profitabilitas (Caroll et al., 2015; Jiwandhana \& Triaryati, 2016)

Penelitian Wei et al. (2017)mendapatkan hasil bahwa likuiditas berpengaruh negatif dan signifikan terhadap keputusan hedging dengan argumen bahwa perusahaan dengan tingkat likuiditas yang tinggi cenderung melakukan penggunaan hedging yang rendah. Penelitian yang dilakukan oleh Mediana \& Muharam (2016) serta Nyamweya \& Ali (2016) berbanding terbalik dengan penelitian sebelumnya yang menunjukan hasil bahwa likuiditas berpengaruh positif dan signifikan terhadap keputusan hedging.

Likuiditas dalam suatu perusahaan dapat ditunjukkan dengan besar kecilnya aktiva lancar dimiliki. Suatu perusahaan harus menjaga tingkat likuiditas dengan mempertahankan aktiva lancar yang dimiliki perusahaan yang bernilai lebih besar daripada utang. Perusahaan dengan tingkat likuiditas yang tinggi menunjukkan bahwa perusahaan tersebut mampu memenuhi kewajiban jangka pendeknya dengan menggunakan dana cadangan yang dimiliki, sehingga penggunaan hedging tidak perlu dilakukan karena memiliki risiko kesulitan keuangan yang 
rendah.Keputusan hedging sangat diperlukan pada perusahaan yang memiliki tingkatrasio leverage yang tinggi, karena dapat membantu perusahaan dalam menghadapi risiko fluktuasi nilai tukar. Apabila terjadi fluktuasi kurs yang signifikan di masa mendatang, maka akan menyebabkan perusahaan kesulitan untuk memenuhi kewajibannya, sehingga peran hedging sangat diperlukan untuk meminimalisir risiko tersebut. Pengukuran leverage dalam penelitian ini menggunakan jenis ratioDept to Equity (DER). DER merupakan ratio yang membandingkan hutang jangka panjang dengan modal sendiri, untuk mengetahui besarnya penggunaan hutang jangka panjang dibandingkan dengan modal sendiri, serta dapat menunjukan kemampuan modal sendiri dalam multinasional corporation, sehingga dapat dikatakan mampu memenuhi kewajiban perusahaan.Guniarti (2014) dan Butt et al. (2018) bahwa leverage berpengaruh positif dan signifikan terhadap keputusan hedging dengan alasan bahwa beberapa perusahaan masih banyak yang menggunakan ekuitas daripada utang. Penelitian dari Velasco (2015), Yavas (2016) serta Nyamweya \& Ali (2016) berbanding terbalik dengan penelitian sebelumnya yang menyatakan bahwa leverage berpengaruh negatif dan signifikan terhadap keputusan hedging.

Faktor internal lainnya yang dapat mempengaruhi perusahaan melakukan keputusan hedging adalah profitabilitas. Profitabilitas merupakan kemampuan suatu perusahaan untuk memperoleh laba atau ukuran efektivitas pengelolaan manajemen perusahaan. Satu faktor yang menciptakan nilai masa depan untuk menarik investor baru yaitu return yang dihasilkan oleh perusahaan tersebut. Pengukuran profitabilitas dalam penelitian ini diproksikan dengan return on asset (ROA). ROA merupakan salah satu rasio yang perlu diperhatikan oleh perusahaan, karena dapat menunjukkan bagaimana suatu perusahaan memperoleh laba dari total aktiva perusahaan. Dalam aktivitas hedging, perusahaan dengan tingkat profitabilitasnya yang tinggi memiliki tingkat kesulitan keuangan yang rendah sehingga memiliki kecenderungan tidak akan melakukan hedging

Caroll et al. (2015) dan Candradewi \& Rahyuda (2018) melakukan penelitian yang menunjukkan bahwa profitabilitas berpengaruh negatif terhadap keputusan hedging dengan argumen bahwa semakin tinggi tingkat profit perusahaan menyebabkan perusahaan terhindar dari risiko financial distress dan cenderung tidak melakukan hedging. Penelitian yang dilakukan oleh Jiwandhana \& Triaryati (2016)bertolak belakang dengan penelitian sebelumnya, yang menemukan hasil bahwa profitabilitas berpengaruh positif dan signifikan terhadap keputusan hedging dengan argumen perusahaan dengan profitabilitas yang tinggi akan cenderung untuk melakukan ekspansi pasar yang memerlukan peranan hedging untuk meminimalisir risiko yang akan dihadapi dalam pasar internasional. Berdasarkan fenomena yang telah dijelaskan dan pernyataan dari penelitian sebelumnya, masih adanya research gap dari variabel-variabel yang diteliti. Dikarenakan masih adanya permasalahan dan perbedaan pendapat dari berbagai penelitian sebelumnya, maka dibutuhkan penelitian lebih lanjut untuk mengetahui pengaruh likuiditas, leverage dan profitabilitas terhadap keputusan hedging.

Penelitian ini memfokuskan pada perusahaan sektor pertambangan. Kementrian Energi dan Sumber Daya Mineral (ESDM) mencatat bahwa 
Pendapatan Negara Bukan Pajak (PNBP) dari sektor pertambangan mineral dan batubara pada tahun 2017 mencapai target sebesar Rp. 40,6 triliun yang menembus target $125 \%$ dari Anggaran Pendapatan dan Belanja Negara Perubahan (APBNP) 2017 sebesar Rp. 32,7 triliun. Membaiknya PNBP dari sektor pertambangan diakibatkan oleh kenaikan ekspor dan harga komoditas, baik mineral maupun batu bara sepanjang tahun 2017 (www.esdm.go.id). Semakin tinggi pertumbuhan ekspor yang dilakukan oleh suatu perusahaan sektor pertambangan, cenderung memiliki risiko kerugian yang lebih tinggi akibat adanya fluktuasi nilai tukar. Fenomena ini menyebabkan perusahaan sektor pertambangan akan sangat dipengaruhi oleh fluktuasi nilai tukar sehingga memiliki eksposur valuta asing yang lebih besar.

Tujuan dari penelitian ini adalah sebagai berikut : 1) Untuk mengetahui signifikansi pengaruh likuiditas terhadap keputusan hedging pada sektor pertambangan di Bursa Efek Indonesia (BEI). 2) Untuk mengetahui signifikansi pengaruh leverage terhadap keputusan hedging pada sektor pertambangan di Bursa Efek Indonesia (BEI). 3) Untuk mengetahui signifikansi pengaruh profitabilitas terhadap keputusan hedging pada sektor pertambangan di Bursa Efek Indonesia (BEI).

Rasio likuiditas merupakan rasio yang digunakan untuk mengetahui tingkat kemampuan perusahaan dalam memenuhi kewajiban jangka pendeknya. Suatu perusahaan akan menghadapi risiko likuiditas ketika perusahaan tidak mampu memenuhi kewajibannya yang sudah jatuh tempo. Jika suatu perusahaan tidak mampu memenuhi kewajibannya yang sudah jatuh tempo, maka perusahaan tersebut akan mengalami financial distress cost. Semakin likuid suatu perusahaan dengan tingkat rasio likuiditas yang tinggi maka semakin kecil risiko kesulitan keuangan yang dialami, sehingga perusahaan cenderung tidak menerapkan keputusan hedging, karena aktiva lancar yang dimiliki perusahaan lebih besar dibandingkan utang lancar yang dimiliki.

Pernyataan ini sesuai dengan hasil penelitian terdahulu yang dilakukan oleh Megawati \& Wiagustini (2016); Chaudry et al. (2015), Zuhroh (2019), Altuntas et al. (2017), Augusto et al. (2017)Nova et al. (2015)serta Wei et al. (2017) yang menyatakan bahwa variabel likuiditas berpengaruh negatif terhadap keputusan hedging. Berdasarkan penelitian empiris yang mendukung penelitian tersebut, maka bunyi hipotesis pertama sebagai berikut :

$\mathrm{H}_{1}$ : Likuiditas berpengaruh negatif terhadap keputusan hedging.

Penggunaan utang merupakan salah satu alternatif pendanaan bagi perusahaan dalam meningkatkan kinerjanya. Penggunaan utang dalam perusahaan membawa keuntungan dan kerugian. Keuntungan dari penggunaan utang adalah bunga yang dibayarkan atas utang dapat menjadi pengurang pajak, sementara kerugiannya yaitu perusahaan dapat mengalami risiko kesulitan keuangan. Semakin tinggi tingkat hutang dibandingkan modal sendiri, maka risiko yang ditanggung perusahaan juga semakin tinggi. Pada teori Modigliani Miller menjelaskan bahwa penggunaan utang yang lebih tinggi dibanding modal sendiri akan menimbulkan permasalahan baru, seperti meningkatnya biaya kebangkrutan, biaya keagenan dan tingkat pengembalian bunga yang tinggi. 
Penggunaan utang yang lebih besar pada suatu perusahaan mengakibatkan perusahaan memiliki kecenderungan untuk melakukan hedging, karena tingkat rasio leverage yang tinggi dapat menyebabkan perusahaan mengalami risiko financial distress, dimana pembiayaan utang dengan proporsi yang lebih tinggi dan rendahnya pembiayaan ekuitas dalam perusahaan tersebut.Hal ini sesuai dengan penelitian yang dilakukan oleh Iqbal (2015), Yong et al. (2015), Butt et al. (2018)dan Klingeberg et al. (2018) yang menunjukkan bahwa leverage berpengaruh positif dan signifikan terhadap keputusan hedging. Berdasarkan penelitian empiris yang mendukung penelitian tersebut, maka bunyi hipotesis kedua sebagai berikut :

$\mathrm{H}_{2}$ : Leverage berpengaruh positif terhadap keputusan hedging.

Profitabilitas merupakan tingkat return bersih yang dapat dicapai oleh perusahaan dalam menjalankan operasi bisnisnya. Perusahaan dengan profitabilitas yang tinggi mencerminkan perusahaan memiliki prospek keuangan yang baik. Semakin tinggi tingkat return yang diraih suatu perusahaan, maka akan terlihat bahwa suatu perusahaan mengelola dengan baik tingkat pengembalian laba kepada investor, efisiensi dan kinerja perusahaan tersebut. Perusahaan dengan tingkat profitabilitas yang tinggi memiliki kecenderungan untuk tidak menerapkan hedging dalam aktivitas perusahaannya, karena dengan memiliki tingkat profitabilitas yang tinggi perusahaan akan terhindar dari ancaman risiko financial distress sehingga tidak diperlukannya intrumen lindung nilai (hedging) untuk meminimalisir risiko. Penelitian empiris yang dilakukan oleh Caroll et al. (2015), Candradewi \& Rahyuda (2018) dan Kurniawan \& Asandimitra (2018) menemukan bahwa variabel profitabilitas berpengaruh negatif terhadap keputusan hedging. Berdasarkan penelitian empiris yang mendukung penelitian tersebut, maka bunyi hipotesis ketiga sebagai berikut :

$\mathrm{H}_{3}$ : Profitabilitas berpengaruh negatif terhadap keputusan hedging

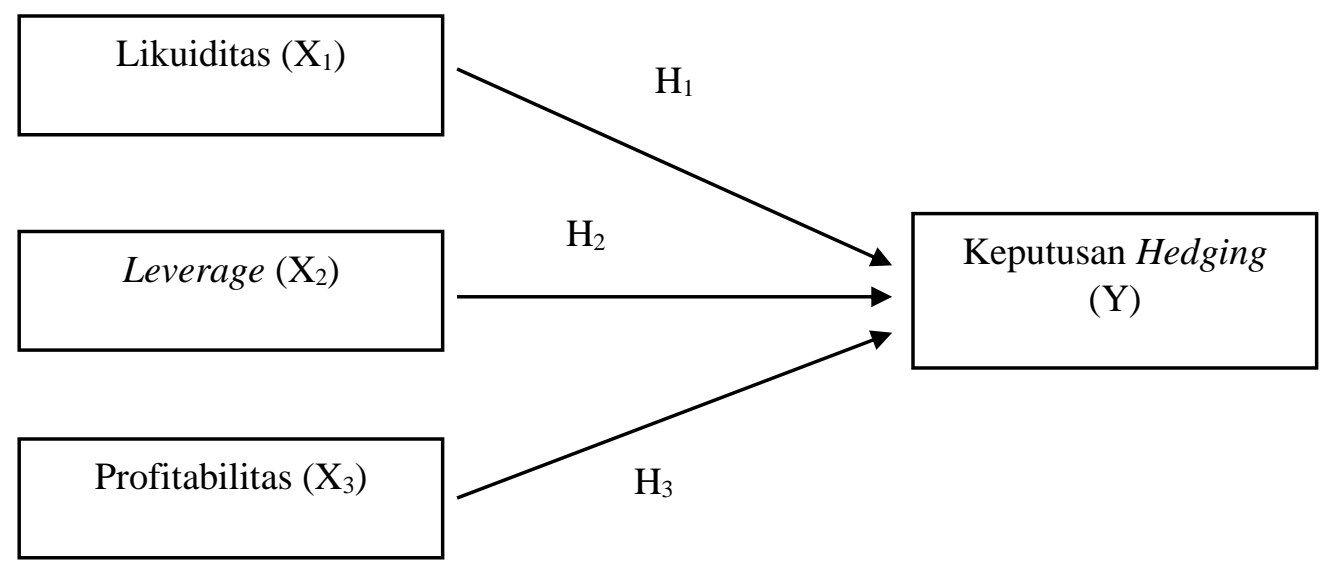

\section{Gambar 2. Kerangka Konseptual}

\section{METODE PENELITIAN}

Pendekatan yang akan digunakan dalam penelitian ini adalah pendekatan kuantitatif dengan bentuk asosiatif, yaitu untuk mengetahui pengaruh likuiditas, 
leverage dan profitabilitas terhadap keputusan hedging perusahaan. Lokasi penelitian ini dilakukan pada perusahaan pertambangan yang terdaftar dalam Bursa Efek Indonesia (BEI). Lokasi penelitian tersebut dapat diakses melalui situs resmi Bursa Efek Indonesia (BEI), yaitu www.idx.co.id. Data yang didapatkan dalam bentuk laporan tahunan dan laporan historis lainnya di BEI periode 2016-2018. Obyek yang diteliti dalam penelitian ini adalah keputusan hedging perusahaan pertambangan yang terdaftar di Bursa Efek Indonesia (BEI) pada periode 2016-2018. Variabel terikat dalam penelitian ini adalah keputusan hedging $(\mathrm{Y})$. Variabel bebas yang akan digunakan yaitu likuiditas $\left(\mathrm{X}_{1}\right)$, leverage $\left(\mathrm{X}_{2}\right)$ dan profitabilitas $\left(\mathrm{X}_{3}\right)$.

Hedging merupakan suatu kebijakan perusahaan dalam meminimalisir risiko yang disebabkan oleh perubahan kurs yang berfluktuasi. Aktivitas hedging dilakukan dengan menggunakan instrumen derivatif seperti opsi, kontrak forward, kontrak future, dan swap. Hedging dinyatakan dalam variabel dummy, apabila perusahaan sektor pertambangan yang terdaftar di BEI menggunakan instumen derivatif sebagai aktivitas hedging, diberi angka 1 sebagai kategori bahwa perusahaan melakukan aktivitas hedging, dan diberi angka 0 apabila perusahaan tersebut tidak menggunakan instrumen derivatif.

Likuiditas dalam penelitian ini diproksikan dengan Current Ratio. Current Ratio dihitung dengan membandingkan aktiva lancar dengan utang lancar yang dimiliki oleh perusahaan sektor pertambangan yang terdaftar di BEI periode 2016-2018. Formula current ratio dapat dihitung menggunakan rumus dengan satuan persen (\%).

Current Ratio $=\frac{\text { Aktiva Lancar }}{\text { Utang Lancar }} \times 100 \%$

Leverage dalam penelitian ini diproksikan dengan DER (dept to equity ratio). DER digunakan untuk menilai perbandingan hutang terhadap ekuitas pada perusahaan sektor pertambangan yang terdaftar di BEI pada periode 2016-2018. DER dapat dihitung menggunakan rumus dengan satuan persen (\%).

DER $=\frac{\text { Total Hutang }}{\text { Total Modal Sendiri }} \times 100 \%$

Profitabilitas dalam penelitian ini diproksikan dengan ROA (return on asset). Penggunaan ROA dapat mencerminkan efektivitas kinerja suatu perusahaan untuk mendapatkan keuntungan pada perusahaan sektor pertambangan yang terdaftar di BEI pada periode 2016-2018. ROA dapat di hitung dengan menggunakan rumus dengan satuan persen $(\%)$.

$R O A=\frac{\text { Laba Bersih Setelah Pajak }}{\text { Total Aset }} \times 100 \%$

Data yang digunakan dalam penelitian ini berupa data kuantitatif yang berisikan variabel bebas dan variabel terikat yang diperoleh pada perusahaan sektor pertambangan di BEI. Data yang didapatkan berbentuk laporan tahunan dan laporan historis lainnya untuk periode 2016-2018. Penelitian ini menggunakan sumber data berupa data sekunder. Data sekunder merupakan data yang diperoleh dalam bentuk yang sudah ada, sudah dikumpulkan, dan diolah oleh pihak lain. Data yang digunakan dalam penelitian ini diakses dari website 
resmi BEI (www.idx.co.id). Populasi dalam penelitian ini adalah seluruh perusahaan sektor pertambangan di BEI periode 2016-2018 yaitu sebanyak 47 perusahaan.

Penentuan sampel dalam penelitian ini menggunakan metode purposive sampling, yaitu pengambilan sampel dari suatu populasi dengan kriteria tertentu. Adapun kriteria yang digunakan dalam penelitian ini adalah sebagai berikut : 1) Perusahaan sektor pertambangan yang listing di Bursa Efek Indonesia (BEI) periode 2016-2018. 2) Perusahaan sektor pertambangan yang menerbitkan laporan keuangan secara kontinyu yang telah diaudit pada periode 2016-2018. 3) Perusahaan sektor pertambangan yang memiliki eksposur valuta asing yang timbul dari impor bahan baku, penjualan ekspor, serta aset dan kewajiban dalam valuta asing, atau memiliki anak perusahaan di luar negeri.

Penelitian ini menggunakan metode pengumpulan data berupa metode observasi non partisipan. Metode ini memperoleh data dengan melakukan pengumpulan melalui pengamatan dan mencatat serta mempelajari uraian-uraian data dari website resmi BEI melalui www.idx.co.id, data tersebut diperoleh dalam bentuk laporan tahunan perusahaan sektor pertambangan beserta catatannya dari tahun 2016-2018. Data yang diperoleh dari website BEI didapatkan jumlah populasi sebanyak 47 perusahaan sektor pertambangan. Setelah dilakukannya seleksi sampel dengan kriteria yang telah disebutkan diatas maka diperoleh sampel sebanyak 40 perusahaan pertambangan yang memenuhi kriteria dan 7 perusahaan pertambangan yang tidak memenuhi kriteria.

\section{Tabel 1.}

Jumlah Populasi dan Sampel Penelitian

\begin{tabular}{lc}
\hline \multicolumn{1}{c}{ Keterangan } & Frekuensi \\
\hline Populasi & 47 \\
Perusahaan delisting & 2 \\
Perusahaan yang tidak menerbitkan laporan & 5 \\
keuangan secara kontinyu & \\
$\begin{array}{l}\text { Perusahaan yang tidak memiliki eksposur valuta } \\
\text { asing }\end{array}$ & 0 \\
$\quad$ Jumlah Sampel & 40 \\
\hline
\end{tabular}

Sumber: Data Diolah, 2019

\section{HASIL DAN PEMBAHASAN}

Penelitian ini dilakukan pada perusahaan pertambangan yang terdaftar di Bursa Efek Indonesia yang dimulai pada tahun 2016 hingga 2018. Perusahaan sektor pertambangan terbagi dalam 5 subsektor, yaitu subsektor pertambangan batu bara, subsektor pertambangan gas dan minyak bumi, subsektor pertambangan logam dan mineral, subsektor pertambangan batu-batuan, dan subsektor pertambangan lainnya. Populasi perusahaan pertambangan pada penelitian ini 
yang terdaftar di Bursa Efek Indonesia periode tahun 2016-2018 berjumlah 47 perusahaan.

Penelitian ini menjadikan perusahaan pertambangan sebagai obyek penelitian didasarkan pada pertimbangan yaitu perusahaan dalam sektor ini yang telah go - public, dan salah satu sektor yang sering melakukan transaksi dengan pihak asing. Perusahaan pertambangan dalam mendapatkan bahan baku untuk memenuhi kegiatan operasional tidak hanya didapatkan dari dalam negeri saja. Melalui kegiatan internasional seperti ekspor maupun impor, perusahaan pertambangan dapat memenuhi bahan baku dan peralatannya untuk melancarkan kegiatan operasional perusahaan. Kegiatan pertambangan dimulai dari mencari, menemukan, menambang, mengolah, hingga memasarkan bahan galian (mineral, batubara dan migas) yang bernilai ekonomis. Kegiatan pengiriman barang, peralatan, pinjaman barang maupun modal yang dilakukan perusahaan pertambangan memungkinkan perusahaan melakukan keputusan hedging yang cukup tinggi. Perusahaan pertambangan yang dijadikan sampel dalam penelitian ini berjumlah 40 sampel.

Data yang digunakan dalam penelitian ini menggunakan data sekunder. Data sekunder yang digunakan dalam penelitian ini didapatkan melalui publikasi dari laporan keuangan tahunan perusahaan pertambangan di Bursa Efek Indonesia. Adapun data sampel yang digunakan dalam penelitian ini yaitu likuditas yang diukur menggunakan current ratio, leverage yang diukur menggunakan rasio DER, dan profitabilitas yang diukur menggunakan rasio ROA. Teknik analisis data pada penelitian ini menggunakan teknik regresi logistik dengan menggunakan beberapa uji seperti menguji koefisien regresi dengan menggunakan nilai pada tabel variable in equation, kelayakan model dengan menggunakan nilai dari hosmer and lemeshow's goodness of fit, menilai keseluruhan model dengan menggunakan nilai dari log likehood value, koefisien determinasi dengan menggunakan nilai dari Nagelkerke $R$ Square, matriks klasifikasi dengan menggunakan nilai dari matriks klasifikasi, multikolinieritas dengan menggunakan nilai dari matriks kolerasi, serta uji $\mathrm{T}$ menggunakan nilai pada variable in the equation.

Statistik deskriptif digunakan untuk memberikan deskripsi suatu data yang dilihat dari rata-rata (mean), standar deviasi (standard deviation), dan maksimum minimum. Mean digunakan untuk memperkirakan besar rata-rata populasi yang diperkirakan dari sampel. Hasil uji statistik deskriptif dalam penelitian ini dapat di deskripsikan seperti yang tersaji pada Tabel 2. berikut:

Tabel 2.

Statistik Deskriptif Variabel Bebas

\begin{tabular}{lccccc}
\hline & N & Minimum & Maximum & Mean & Std. Deviation \\
\hline CR & 120 & 5.24 & 710.29 & 170.8196 & 134.07176 \\
DER & 120 & 15.00 & 2430.00 & 209.6917 & 346.98109 \\
ROA & 120 & -41.59 & 39.41 & 4.5483 & 10.66537 \\
Valid N (listwise) & 120 & & & & \\
\hline
\end{tabular}

Sumber: Data Diolah, 2019 
Dari data pada Tabel 2. dapat dilihat bahwa nilai minimum dari CR sebagai variabel pertama adalah sebesar 5,24 yang terdapat pada PT. Astrindo Nusantara Infrastruktur Tbk tahun 2016 sedangkan nilai maksimum dari variabel CR adalah sebesar 710,29 yang terdapat pada PT. Ratu Prabu Energi Tbk tahun 2018. Rata - rata variabel Current Ratio sebesar 170,8196 dan standar deviasi sebesar 134,07176. Pada variabel kedua yaitu dept to equity ratio didapatkan nilai minimum sebesar 15,0 yang terdapat pada PT. Garda Tujuh Buana Tbk tahum 2018 sedangkan nilai maksimum dari variabel dept to equity ratio sebesar 2430,0 yang terdapat pada PT. Apexindo Pratama Duta Tbk tahun 2016. Rata - rata dari variabel dept to equity ratio sebesar 209,6917 dan standar deviasi dari variabel ini sebesar 346,98109. Nilai minimum dari variabel ROA adalah sebesar -41,59 yang terdapat pada PT. Energi Mega Persada Tbk tahun 2016 sedangkan nilai maksimum dari variabel ROA adalah sebesar 38,03 yang terdapat pada PT. Baramulti Suksessarana Tbk tahun 2017. Rata - rata variabel ROA yaitu sebesar 4,5483 dengan standar deviasi sebesar 10,66537. Sampel dengan variabel hedging (Y) dapat dilihat pada Tabel 3.

Tabel 3.

Frekuensi Variabel Terikat

\begin{tabular}{cccccc}
\hline & & Frequency & Percent & Valid Percent & Cumulative Percent \\
\hline Valid & 0 & 52 & 43.3 & 43.3 & 43.3 \\
& 1 & 68 & 56.7 & 56.7 & 100.0 \\
& Total & 120 & 100.0 & 100.0 & \\
\hline
\end{tabular}

Sumber: Data Diolah, 2019

Pada penelitian ini perusahaan sektor pertambangan yang melakukan aktivitas hedging diberi kode 1 sedangkan perusahaan sektor pertambangan yang tidak melakukan hedging diberi kode 0. Berdasarkan Tabel 3 . dapat dilihatbahwa terdapat aktivitas hedging yang dilakukan oleh perusahaan sektor pertambangan sebanyak 68 kali dan persentase sebesar 56,7\% sedangkan terdapat 52 kali aktivitas perusahaan dengan kategori tidak menggunakan hedging dan persentase sebesar $43,3 \%$.

Tabel 4.

Hosmer and Lemeshow Test

\begin{tabular}{cccc}
\hline Step & Chi-square & df & Sig. \\
\hline 1 & 1.891 & 8 & .984 \\
\hline Sumber $:$ Data Diolah, 2019 & &
\end{tabular}

Dari Tabel 4.model regresi pada penelitian ini menunjukkan nilai statistik Hosmer and Lemeshow dapat dilihat bahwa nilai signifikansi sebesar 0,984 yang lebih besar dari 0,05 maka hipotesis nol diterima dan berarti model ini mampu menjelaskan hubungan variabel independen dan variabel dependennya atau dapat dikatakan model diterima karena cocok dengan data observasinya.

Penilaian keseluruhan model dapat dinilai dengan membandingkan nilai antara -2 Log likelihood (-2LL) pada awal (Block Number - 0) dengan nilai -2 
Log likelihood (-2LL) pada akhir (Block Number - 1). Apabila terdapat penurunan nilai likelihood, ini menunjukkan model regresi yang baik atau dengan kata lain model yang dihipotesiskan fit dengan data.

Tabel 5.

Iteration History ${ }^{\text {a.b.c.d }}$ Block Number=0

\begin{tabular}{|c|c|c|c|}
\hline \multirow{2}{*}{\multicolumn{2}{|c|}{ Iteration }} & \multirow[b]{2}{*}{-2 Log likelihood } & Coefficients \\
\hline & & & Constant \\
\hline \multirow[t]{3}{*}{ Step 0} & 1 & 164.216 & .267 \\
\hline & 2 & 164.216 & .268 \\
\hline & 3 & 164.216 & .268 \\
\hline
\end{tabular}

Sumber: Data Diolah, 2019

Tabel 6.

Iteration History $^{\mathrm{a}, \mathrm{b}, \mathrm{c}, \mathrm{d}}$ Block Number $=1$

\begin{tabular}{|c|c|c|c|c|c|c|}
\hline \multirow{2}{*}{\multicolumn{2}{|c|}{ Iteration }} & \multirow{2}{*}{$\begin{array}{c}-2 \text { Log } \\
\text { likelihood } \\
\end{array}$} & \multicolumn{4}{|c|}{ Coefficients } \\
\hline & & & Constant & $\mathrm{CR}$ & DER & ROA \\
\hline \multirow[t]{5}{*}{ Step 1} & 1 & 138.178 & 1.004 & -.004 & .001 & -.043 \\
\hline & 2 & 136.296 & 1.085 & -.004 & .001 & -.057 \\
\hline & 3 & 136.116 & 1.020 & -.004 & .002 & -.059 \\
\hline & 4 & 136.110 & 1.002 & -.004 & .002 & -.059 \\
\hline & 5 & 136.110 & 1.001 & -.004 & .002 & -.059 \\
\hline
\end{tabular}

Sumber: Data Diolah, 2019

Iteration History (Blok Number - 0) dan Iteration History (Blok Number - 1) menunjukan hasil nilai antara -2 log likelihood (-2LL) pada awal adalah sebesar 164,216 (Block Number $=0$ ) sedangkan nilai -2 Log Likelihood (-2LL) pada akhir adalah sebesar 136,110 (Block Number =1). Terdapat penurunan nilai likelihood (-2LL), hal ini menunjukan model regresi yang baik atau dengan kata lain model yang dihipotesiskan fit atau cocok dengan data.

Model regresi yang baik adalah dengan tidak adanya gejala korelasi yang kuat antara variabel bebasnya. Uji multikolinieritas dalam regresi logistik dapat dilihat dari tabel matrik kolerasi. Apabila nilai matrik kolerasi lebih kecil dari 0,8 artinya tidak terdapat gejala multikolinieritas yang serius antar variabel tersebut. Tabel 7 menunjukkan matriks korelasi antar variabel bebas.

Tabel 7.

Correlation Matrix

\begin{tabular}{llcccc}
\hline & & Constant & CR & DER & ROA \\
\hline Step 1 & Constant & 1.000 & -.758 & -.639 & -.264 \\
& CR & -.758 & 1.000 & .313 & -.093 \\
& DER & -.639 & .313 & 1.000 & .164 \\
& ROA & -.264 & -.093 & .164 & 1.000 \\
\hline
\end{tabular}

Sumber: Data Diolah, 2019 
Hasil Tabel 7. menunjukkan tidak terdapat nilai koefisien antar variabel yang lainnya, dapat dilihat bahwa nilai matriks korelasi antar variabel lebih kecil dari 0,8 . Sehingga tidak terdapat gejala multikolinieritas yang serius antar variabel tersebut.

Matriks klasifikasi menunjukkan kekuatan prediksi dari model regresi untuk memprediksi kemungkinan terjadinya keputusan hedging pada sektor pertambangan di Bursa Efek Indonesia (BEI) pada periode 2016-2018. Hasil tabel kualifikasi ditampilkan pada Tabel 8.

Tabel 8.

Classification Table ${ }^{a}$

\begin{tabular}{|c|c|c|c|c|c|}
\hline & & & & & ted \\
\hline & & & & & \\
\hline & Observed & & 0 & 1 & Percentage Correct \\
\hline Step 1 & Hedging & 0 & 28 & 24 & 53.8 \\
\hline & & 1 & 11 & 57 & 83.8 \\
\hline & Overall $\mathrm{Pe}$ & centage & & & 70.8 \\
\hline
\end{tabular}

Sumber: Data Diolah, 2019

Berdasarkan Tabel 8. menjelaskan bahwa kekuatan prediksi untuk perusahaan yang melakukan hedging adalah sebesar 83,8 \%, hal tersebut mengartikan bahwa dengan penggunaan model regresi terdapat sebanyak 57 observasi yang diprediksi akan melakukan hedging dari total 68 observasi yang melakukan hedging. Kekuatan prediksi untuk kemungkinan perusahaan tidak melakukan hedging sebesar 53,8 \%, hal tersebut mengartikan bahwa dengan penggunaan model regresi terdapat sebanyak 28 observasi yang tidak melakukan hedging dari total 52 observasi yang tidak melakukan hedging. Secara keseluruhan, ketepatan klasifikasi pada model regresi ini adalah adalah $70,8 \%$.

Koefisien determinasi dilihat dari besarnya nilai Nagelkerke $R$ Square antara variabel independen terhadap variabel dependen. Nilai dari Nagelkerke $R$ Square dapat menjelaskan sejauh mana kemampuan model dalam menerangkan variasi total dari variabel dependen yang mampu dijelaskan oleh variabel independen. Tabel 4.8 menunjukkan niali Nagelkerke $R$ Square sebesar 0,280. Nilai tersebut berarti bahwa variasi dari variabel Current Ratio, Dept To Equity Ratio dan Return On Asset (variabel independen) mampu menjelaskan variasi dari hedging (variabel dependen) sebesar $28 \%$ sedangkan $72 \%$ dijelaskan oleh variasi variabel lain yang tidak dimasukkan dalam model persamaan regresi.

Tabel 9.

Model Summary

\begin{tabular}{llrr}
\hline Step & $\mathbf{- 2}$ Log likelihood & Cox \& Snell R Square & Nagelkerke R Square \\
\hline 1 & $136.110^{\mathrm{a}}$ & .209 & .280 \\
\hline Sumber: Data Diolah, 2019 & &
\end{tabular}


Uji parsial atau uji $\mathrm{t}$ merupakan uji yang digunakan untuk mengetahui pengaruh masing-masing variabel bebas terhadap variabel terikat secara parsial. Jika masing-masing koefisien signifikan dari variabel bebas memiliki nilai lebih kecil dari taraf signifikansi yaitu sebesar 5\% $(0,05)$, maka dapat disimpulkan bahwa variabel bebas berpengaruh signifikan terhadap variabel terikat.

Tabel 10.

Variables in the Equation

\begin{tabular}{|c|c|c|c|c|c|c|c|}
\hline & & B & S.E. & Wald & df & Sig. & $\operatorname{Exp}(B)$ \\
\hline \multirow[t]{4}{*}{ Step $1^{\mathrm{a}}$} & $\mathrm{CR}$ & -.004 & .002 & 5.127 & 1 & .024 & .996 \\
\hline & DER & .002 & .001 & 1.653 & 1 & .199 & 1.002 \\
\hline & ROA & -.059 & .025 & 5.375 & 1 & .020 & .943 \\
\hline & Constant & 1.001 & .487 & 4.233 & 1 & .040 & 2.721 \\
\hline
\end{tabular}

Sumber: Data Diolah, 2019

Dari Tabel 10. dapat dilihat bahwa nilai wald statistik dari masing masing variabel yaitu CR sebesar 5,127, DER sebesar 1,653 dan ROA sebesar 5,375. Untuk menghitung nilai dari uji $\mathrm{t}$ dapat dilakukan dengan mencari akar dari masing - masing nilai wald pada variabel, sehingga didapatkan hasil pada variabel CR sebesar 2,264, DER sebesar 1,286 dan ROA sebesar 2,318. Untuk menghitung uji $\mathrm{t}$ dilakukan dengan membandingkan thitung dengan tabel. Taraf nyata $5 \%: 2=2,5 \%$ (uji dua sisi) dengan derajat kebebasan (df) $n-k=120-3=$ 117. Dengan pengujian dua sisi (signifikansi $=1,980$ ).

Variabel CR dengan nilai thitung $(2,264)>t_{\text {tabel }}(1,980)$ dan nilai signifikansi sebesar 0,024 $<0,05$ mengartikan bahwa variabel $\mathrm{CR}$ berpengaruh signifikan terhadap keputusan hedging. Variabel DERdengan nilai $\mathrm{t}_{\text {hitung }}(1,286)<\mathrm{t}_{\text {tabel }}(1,980)$ dan nilai signifikansi sebesar 0,199>0,05 mengartikan bahwa variabel DER tidak berpengaruh signifikan terhadap keputusan hedging. Variabel ROA dengan nilai $t_{\text {hitung }}(2,318)>t_{\text {tabel }}(1,980)$ dan nilai signifikansi sebesar $(0,020)<(0,05)$ mengartikan bahwa variabel ROA berpengaruh signifikan terhadap terhadap keputusan hedging.

Model regresi logistik dapat dibentuk dengan cara melihat pada nilai estimasi parameter dalam Variable in The Equation. Model regresi logistik yang terbentuk berdasarkan nilai estimasi parameter dalam Variable in The Equation ditampilkan pada Tabel 11.

Model regresi yang terbentuk berdasarkan nilai estimasi parameter dalam Variable in The Equation adalah sebagai berikut:

$\operatorname{Ln} \frac{p}{1-p}=-7,424+0,202 \mathrm{DER}+0,434 \mathrm{SIZE}+0,036 \mathrm{ROA} 1,001-0,004 \mathrm{CR}+$ 0,002 DER - 0,059 ROA

Variabel Current Ratio yang merupakan proksi dari likuiditasmenunjukkan nilai koefisien regresi sebesar -0,004 dengan tingkat $\alpha(5 \%)$ dan sig. sebesar 0,024 . Apabila nilai probabilitas signifikansi lebih kecil dari 0,05 dan nilai koefisien regresi menunjukkan hasil arah yang sama dengan hipotesis variabel likuiditas maka hal ini mengandung arti bahwa $\mathrm{H}_{1}$ diterima. 
Variabel Current Ratio memiliki pengaruh yang negatif dan signifikan terhadap keputusan hedging pada perusahaan sektor pertambangan di Indonesia.

Tabel 11.

Variables in the Equation

\begin{tabular}{|c|c|c|c|c|c|c|c|}
\hline & & B & S.E. & Wald & df & Sig. & $\operatorname{Exp}(B)$ \\
\hline \multirow[t]{4}{*}{ Step $1^{\mathrm{a}}$} & $\mathrm{CR}$ & -.004 & .002 & 5.127 & 1 & .024 & .996 \\
\hline & DER & .002 & .001 & 1.653 & 1 & .199 & 1.002 \\
\hline & ROA & -.059 & .025 & 5.375 & 1 & .020 & .943 \\
\hline & Constant & 1.001 & .487 & 4.233 & 1 & .040 & 2.721 \\
\hline
\end{tabular}

Sumber: Data Diolah, 2019

Variabel Leverage menunjukkan nilai koefisien regresi sebesar 0,002 dengan tingkat $\alpha(5 \%)$ dan sig. sebesar 0,199. Apabila nilai probabilitas signifikansi lebih besar dari 0,05 maka hal ini mengandung arti bahwa $\mathrm{H}_{2}$ ditolak. Variabel Leverage memiliki pengaruh yang positif namun tidak signifikan terhadap keputusan hedging pada perusahaan sektor pertambangan di Indonesia. Variabel Profitabilitas menunjukkan nilai koefisien regresi sebesar 0,059 dengan tingkat $\alpha(5 \%)$ dan sig. sebesar 0,020 . Apabila nilai probabilitas signifikansi lebih besar dari 0,05 maka hal ini mengandung arti bahwa $\mathrm{H}_{2}$ ditolak. Variabel ROA memiliki pengaruh negatif dan signifikan terhadap keputusan hedging pada perusahaan sektor pertambangan di Indonesia.

Hasil pengujian dengan menggunakan regresi logistik menunjukan bahwa Current Ratio yang merupakan proksi dari likuiditas memiliki pengaruh negatif dan signifikan secara statistik terhadap variabel terikat yaitu keputusan hedging dengan menggunakan instrumen derivatif. Hasil menunjukkan bahwa hipotesis satu yang menyebutkan bahwa likuiditasberpengaruh negatif dan signifikan terhadap keputusan hedging dapat diterima.Pernyataan ini sesuai dengan hasil penelitian terdahulu yang dilakukan oleh Megawati \& Wiagustini (2016); Chaudry et al. (2015), serta Wei et al. (2017) yang menyatakan bahwa variabel likuiditas berpengaruh negatif terhadap keputusan hedging.

Rasio likuiditas merupakan rasio yang digunakan untuk mengetahui tingkat kemampuan perusahaan dalam memenuhi kewajiban jangka pendeknya. Suatu perusahaan akan menghadapi risiko likuiditas ketika perusahaan tidak mampu memenuhi kewajibannya yang sudah jatuh tempo. Jika suatu perusahaan tidak mampu memenuhi kewajibannya yang sudah jatuh tempo, maka perusahaan tersebut akan mengalami financial distress cost. Semakin likuid suatu perusahaan dengan tingkat rasio likuiditas yang tinggi maka semakin kecil risiko kesulitan keuangan yang dialami, sehingga perusahaan cenderung tidak menerapkan keputusan hedging, karena aktiva lancar yang dimiliki perusahaan lebih besar dibandingkan utang lancar yang dimiliki.

Hasil uji regresi logistik menemukan hasil bahwa debt to equity ratio yang merupakan proksi dari leverage memiliki pengaruh positif dan namun tidak signifikan secara statistik terhadap variabel terikat yaitu keputusan 
hedging dengan menggunakan instrumen derivatif. Hasil menunjukkan bahwa hipotesis kedua yang menyebutkan bahwa leverage berpengaruh positif dan signifikan terhadap keputusan hedging ditolak. Hasil pengujian ini sesuai dengan penelitian yang dilakukan oleh Jiwandhana \& Triaryati (2016), Sianturi \& Irene (2015) dan Bodroastuti et al. (2019) sebagai alat ukur dari leverage yang juga menemukan hasil bahwa leverage berpengaruh positif dan tidak signifikan terhadap keputusan hedging.

Hasil penelitian yang bernilai positif namun tidak signifikan ini berarti bahwa perusahaan yang melakukan transaksi internasional memiliki hutang yang tidak didenominasi oleh kurs valuta asing. Besarnya hutang dalam suatu perusahaan sebagian besar berasal dari dalam negeri sehingga suatu perusahaan tidak perlu melakukan hedging karena belum membutuhan perlindungan untuk terhindar dari eksposur valuta asing. Perusahaan yang memiliki tingkat hutang yang tinggi belum tentu melakukan hedging, sehingga terdapat hubungan yang terbalik namun tidak signifikan antara debt to equity ratio dengan keputusan hedging.

Hasil uji regresi logistik menemukan bahwa ROA yang merupakan proksi dari Profitabilitas memiliki pengaruh negatif dan signifikan secara statistik terhadap variabel terikat yaitu keputusan hedging dengan menggunakan instrumen derivatif. Hasil ini menunjukkan bahwa hipotesis ketiga yang menyebutkan bahwa profitabilitas berpengaruh negatif dan signifikan terhadap keputusan hedging diterima. Hasil pengujian ini sesuai dengan Penelitian empiris yang dilakukan oleh Caroll et al. (2015), Candradewi \& Rahyuda (2018) dan Kurniawan \& Asandimitra (2018) menemukan bahwa variabel profitabilitas berpengaruh negatif terhadap keputusan hedging.

Profitabilitas merupakan tingkat return bersih yang dapat dicapai oleh perusahaan dalam menjalankan operasi bisnisnya. Perusahaan dengan profitabilitas yang tinggi mencerminkan perusahaan memiliki prospek keuangan yang baik. Semakin tinggi tingkat return yang diraih suatu perusahaan, maka akan terlihat bahwa suatu perusahaan mengelola dengan baik tingkat pengembalian laba kepada investor, efisiensi dan kinerja perusahaan tersebut. Perusahaan dengan tingkat profitabilitas yang tinggi memiliki kecenderungan untuk tidak menerapkan hedging dalam aktivitas perusahaannya, karena dengan memiliki tingkat profitabilitas yang tinggi perusahaan akan terhindar dari ancaman risiko financial distress sehingga tidak diperlukannya instrumen lindung nilai (hedging) untuk meminimalisir risiko.

Variabel likuiditas, leverage dan profitabilitas merupakan salah satu indikator dari kesulitan keuangan yang ditanggung perusahaan. Kesulitan keuangan dapat dilihat dari kemampuan membayar hutang jangka pendek, kemampuan membayar hutang jangka panjang dan kemampuan perusahaan dalam menghasilkan laba. Apabila perusahaan memiliki tingkat hutang yang tinggi maka cenderung akan mendorong perusahaan dalam melakukan hedging hal ini diharapkan agar mampu melindungi perusahaan dari meningkatnya beban utang yang akan ditanggung perusahaan.

Suatu perusahaan apabila memiliki tingkat laba yang tinggi cenderung akan melakukan ekspansi atau perluasan pasar, ketika perusahaan memutuskan 
untuk memperluas pangsa pasar. Tingginya risiko akibat dari perluasan pangsa pasar yang dilakukan oleh perusahaan tentunya akan mendorong perusahaan dalam menggunakan hedging. Penggunaan hedging dengan menggunakan instrumen derivatif merupakan salah satu alat untuk mentransfer risiko. Penggunaan hedging diharapkan mampu dalam meminimalisir risiko yang ditanggung perusahaan dari adanya eksposur valuta asing.

Berdasarkan penelitian yang telah dilakukan dapat diketahuibahwa penelitian mengenai Pengaruh Likuiditas, Leverage dan Profitabilitas terhadap Keputusan Hedging diharapkan menjadi suatu bukti baru dengan hasil yang berbeda dari hipotesis ini untuk manajemen keuangan internasional. Pengolahan data dilakukan dengan menggunakan regresi logistik dengan berbagai uji yang digunakan untuk memperkirakan hubungan antar variabel variabel yang telah ditetapkan sebelumnya. Hasil penelitian ini diharapkan dapat digunakan untuk memperkaya referensi yang berkaitan dengan Current Ratio, Dept To Equity Ratio dan Return On Asset serta keputusan hedging dan diharapkan dapat dijadikan masukan bagi perusahaan sektor pertambangan yang melakukan transaksi internasional agar nantinya dapat mengurangi risiko yang timbul dari adanya eksposur fluktuasi kurs valuta asing.

\section{SIMPULAN}

Hasil penelitian menunjukkan bahwa likuiditas memiliki pengaruh negatif dan signifikan terhadap keputusan hedging, yang berarti bahwa semakin likuid suatu perusahaan atau tingkat likuiditas yang tinggi maka semakin kecil risiko fluktuasi mata uang yang dialami, sehingga perusahaan cenderung tidak menerapkan keputusan hedging. Hasil penelitian menunjukkan bahwa leverage memiliki pengaruh positif namun tidak signifikan terhadap keputusan hedging. Hasil penelitian menunjukkan bahwa profitabilitas memiliki pengaruh negatif dan signifikan terhadap keputusan hedging, yang berarti bahwa perusahaandengan tingkat profitabilitas yang tinggi sedikit kemungkinan mengalami risiko fluktuasi mata uang, sehingga tidak diperlukannya keputusan hedging untuk meminimalisir risiko.

Bagi perusahaan pertambangan yang memiliki tingkat hutang yang tinggi diharapkan menggunakan kebijakan hedging ketika melakukan transaksi internasional agar perusahaan mampu mengurangi bebas hutang yang dimiliki dari risiko fluktuasi kurs valuta asing. Bagi perusahaan pertambangan dengan tingkat profitabilitas yang rendah diharapkan menggunakan kebijakan hedging ketika melakukan transaksi internasional agar perusahaan dapat menghindari risiko-risiko seperti fluktuasi kurs valuta asing. Peneliti selanjutnya disarankan dapat meneliti lebih lanjut mengenai faktor-faktor yang mempengaruhi keputusan hedging selain dari variabel dalam penelitian ini dengan menggunakan perusahaan sektor yang berbeda yang terdapat di Indonesia.

\section{REFERENSI}

Afriyeni, E., \& Jumyetti. (2017). Faktor-Faktor Makro Ekonomi Dalam 
Memprediksi Kondisi Financial Distress. Jurnal Poli Bisnis, 8(2), 1-20.

Altuntas, M., Liebenberg, A. P., Watson, E. D., \& Yildiz, S. (2017). Hedging, Cash Flows, and Firm Value: Evidence of an Indirect Effect. Journal of Insurance Issues, 40(1), 1-22.

Ariani, N. N. N., \& Sudiartha, G. (2017). Pengaruh Leverage, Profitabilitas, Dan Likuiditas Terhadap Keputusan Hedging Perusahaan Sektor Pertambangan Di Bursa Efek Indonesia. E-Jurnal Manajemen Universitas Udayana, 6(1), 347-374.

Augusto, C., Giraldo-Prieto, Jaime, G., Uribe, G., Bermejo, C. V., Carolina, D., \& Herrerad, F. (2017). Financial hedging with derivatives and its impact on the Colombian market value for listed companies. Contaduría $y$ Administración, 62(5), 1572-1590. https://doi.org/https://doi.org/10.1016/j.cya.2017.04.009

Bodroastuti, T., Ekayana, S. P., \& Lia, R. (2019). Faktor-Faktor yang Berpengaruh Terhadap Kebijakan Hedging Perusahaan Di Indonesia. Valid Jurnal Ilmiah, 16(1), 71-84.

Butt, A. A., Sajid, M., Hamera, A., \& Shahzad, A. (2018). Corporate Derivative and Ownership Concentration: Empirical Evidence of Non-Financial Firms Listed on Pakistan Stock Exchange Management. Journal of Risk and Financial, 11(1), 33.

Candradewi, M. R., \& Rahyuda, H. (2018). Variabel -Variabel Penentu Pengguna Derivatif Perusahaan Non- Keuangan Di Bursa Efek Indonesia. Jurnal Manajemen, Strategi Bisnis Dan Kewirausahaan, 12(1), 1-86.

Caroll, A., O'Brien, F., \& Ryan, J. (2015). An Examination of European Firm Derivatives Usage: The Importance of Model Selection. Kemmy Business, l(1), 1 .

Chaudry, N. I., Mehmood, M. S., \& Mehmood, A. (2015). Determinants Of Corporate Hedging Policies and Derivative Usage In Risk Management Practices Of Non-financial Firms. Munica Personal Repec Archive, 1(1), 120.

Iqbal, Z. (2015). Financial Distress Around Introduction of Hedging in the Oil and Gas Industry. International Journal of Business, 20(1), 79-89.

Jiwandhana, R. S. P., \& Triaryati, N. (2016). Pengaruh Leverage Dan Profitabilitas Terhadap Keputusan Hedging Perusahaan Manufaktur Indonesia. E-Jurnal Manajemen Universitas Udayana, 5(1), 31-58. 
Klingeberg, J. G., Hang, M., Rathgeber, A. W., Stöckl, S., \& Walter, M. (2018). What do we really know about corporate hedging? Business Research; Göttingen, 11(1), 1-31.

Krisdian, N. P. C., \& Badjra, I. B. (2017). Pengaruh Ukuran Perusahaan, Tingkat Hutang, Dan Kesulitan Keuangan Terhadap Keputusan HedgingPada Perusahaan Manufaktur Indonesia. E-Jurnal Manajemen Universitas Udayana, 6(3), 1452-1477.

Kurniawan, D. P., \& Asandimitra, N. (2018). Analisis Faktor Yang Mempengaruhi Penggunaan Instrumen Derivatif Sebagai Pengambilan Keputusan Hedging Pada Perusahaan Sektor Keuangan Yang Terdaftar Di Bei Periode 2011-2015. Jurnal Ilmu Manajemen, 6(1), 1-11.

Maniar, H. (2016). Hedging Practices Used by Indian Companies in Managing Foreign Exchange Risk. IUP Journal of Financial Risk Management, 12(1), 1.

Mediana, I., \& Muharam, H. (2016). Analisis Faktor- Faktor Yang Mempengaruhi Pengambilan Keputusan Lindung Nilai (Hedging) Menggunakan Instrumen Derivatif (Studi Kasus Pada Perusahaan Manufaktur Dan Perusahaan Energi Dan Sumber Daya Mineral Yang Terdaftar Di Bursa Efek Indonesia Periode 20. Diponogoro Journal Of Management, 5(2), 70-83.

Megawati, I. A. P., \& Wiagustini, N. L. P. (2016). Determinasi Keputusan Hedging Pada Perusahaan Manufaktur di Bursa Efek Indonesia. E- Jurnal Ekonomi Dan Bisnis Universitas Udayana, 5(10), 3391-3418.

Nova, M., Cerquira, A., \& Brandão, E. (2015). Hedging With Derivatives and Firm Value : Evidence for the non nancial rms listed on the London Stock Exchange. Research Work in Progress, 1(12), 1-47. Retrieved from http://wps.fep.up.pt/wps/wp568.pdf

Nyamweya, L. N., \& Ali, I. (2016). Determinant of Hedging Foreign Risk in Kenya: A Survey of Tea Exporting Companis in Mombasa County. Imperial Journal of Interdisciplinary Research, 2(6), 1-20.

Sianturi, C. N., \& Irene, R. D. (2015). Pengaruh Liquidity, Firm Size, Growth Opportunity, Financial Distress, Leverage, dan Managerial Ownership Terhadap Aktivitas Hedging Dengan Instrumen Derivatif. Diponegoro Jurnal of Management, 4(4), 1-13.

Velasco, L. G. (2015). Factors Influencing Derivatives Usage by Selected Listed Companies in the Philippines. Phillipine Management Review, 21(1), 1-12.

Wei, P., Li, X., \& Bei, Z. (2017). Corporate Hedging, Firm Focus and Firm Size: 
Putu Mia Anggyantari, Pengaruh Beberapa Rasio...

The Case of REITs. Managerial Finance. Patrington, 2(3), 313-330.

Yavas, C. V. (2016). Determinantsof Corporate Hedging: Evidance from Emerging Market. International Journal of Economics and Finance, 8(12), $1-20$.

Yong, H. H. A., Faff, R., \& Chalmersa, K. (2015). Determinants of the extent of Asia-Pacific banks' derivative activities. Accounting and Management Information Systems. 13(3), 430-448.

Zuhroh, I. (2019). Determinants Of Hedging Decision With Derivative Instruments In Manufacturing Companies Listed On Indonesia Stock Exchange Period 2013-2016. KnE Social Sciences, 1(1), 1. https://doi.org/10.18502/kss.v3i13.4206 